\title{
流束曲線による回分沈降の解析 (II)*
}

Analysis of Batch Sedimentation with Solid Flux Curve

渡 㲽 治 ${ }^{* *}$

Haruo Watanabe

\section{5. 回分沈降曲線の一般的表現}

回分沈降曲線の横軸 $t$ と縦軸 $z$ を， $X=t / c_{0} z_{0} ， Y=z /$ $c_{0} z_{0}$ にすると, $c_{0} z_{0}\left(=c_{\infty} z_{\infty}\right)$ が一定のスラリーでは,

Fig. 13のように，沈降終了時にすべての曲線が $1 / c_{\infty}$ に 一致するようになることが知られている7。。の関係を 用いて, 固体流束曲線から回分沈降曲線を求めることを 考えてみる

\section{1 固体流束曲線と $\boldsymbol{X}-\boldsymbol{Y}$ 曲線との関係}

回分沈降に和いて, 清澄界面の沈降速度を $U_{s}$ とする と, Fig. 14 の流束曲線では, $U_{s}$ は $c=0$ と界面直下の 濃度 $c$ とを結ぶ弦の傾きで表わされ, (8) 式より, $U_{s}=$ $c v / c=v$ である。また， $U_{s}$ は，回分沈降曲線に㧧いて

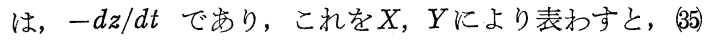
式の関係が得られる。

$$
U_{s}=\frac{c v}{c}=-\frac{d z}{d t}=-\frac{d Y}{d X}
$$

濃度 $c$ の等濃度層の上昇速度を $U_{c}$ とすると, 時刻 $t$ に拉いて，管底部から上昇してくる等濃度層の位置は, $z=U_{c} t$ で与えられ, また, (6)式より $U_{c}=-d(c v) / d c$ で,

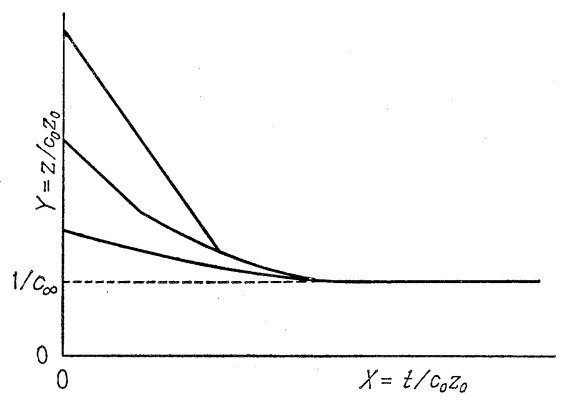

Fig. 13 回分沈降曲線, $c_{0} z_{0}=$ 一定

昭和 49 年 4 月 26 日受理
** 室蘭工業大学化学工学科（广０50 室蘭市水元町 $27 ）$

T EL $\quad 0143-44-4181$
固体流束曲線にたいする接線の傾きとして表わされ，さ らに, $z-t$ 曲線では原点を通る直線の傾き， $z / t$ とな る。したがって，(36)式の関係が得られる。

$$
U_{c}=-\frac{d(c v)}{d c}=\frac{z}{t}=\frac{Y}{X}
$$

Fig. 14 に, 固体流束曲線の $\mathrm{S}$ 点に和将る $U_{s}$ と $U_{c}$ の 関係を示す。 $\mathrm{M}$ は固体流束曲線の最大， $\mathrm{P}$ は変曲点を示 す。

$X=t / c_{0} z_{0}, Y=z / c_{0} z_{0}$ の平面上で，沈降曲線が Fig. 15 の $\mathrm{RS}^{\prime} \mathrm{T}$ 曲線のように表わされるとすると， $\mathrm{S}^{\prime}$ 点に特 ける清澄界面の沈降速度 $U_{s}$ は, $\mathrm{S}^{\prime}$ 点に打ける沈降曲線 への接線の傾きであり, 界面直下の濃度 $c$ の等濃度層の 上昇速度 $U_{c}$ は, 原点と $\mathrm{S}^{\prime}$ を結ぶ直線の傾きで表わされ

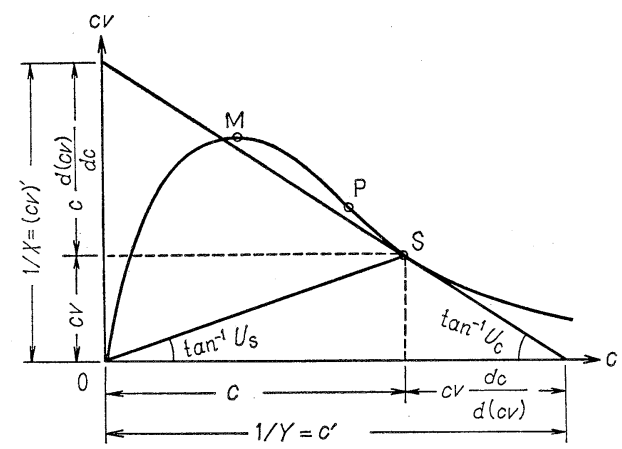

Fig. 14 流束曲線と $X, Y$ の関係, $c_{0} z_{0}=$ 一定

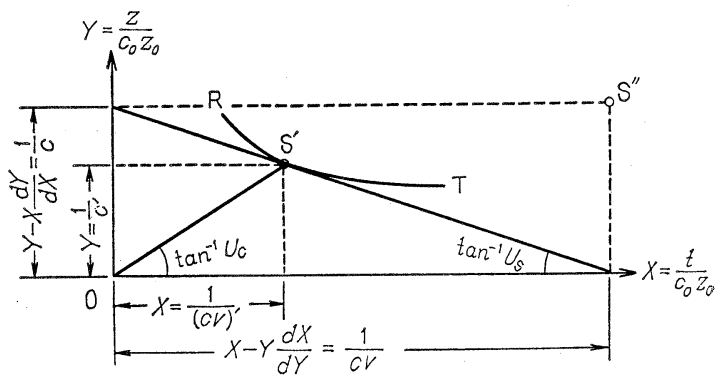

Fig. $15 X, Y$ 面上の沈降曲線, $c_{0} z_{0}=$ 一定 
る。

清澄界面直下の濃度 $c$ は, $\mathrm{S}^{\prime}$ 亿淤ける曲線への接線と $Y$ 軸との交点 $Y_{i}=z_{i} / c_{0} z_{0}$ に相当する濃度であり, さら に, $c_{0} z_{0}=c z_{i}$ の関係から， $z_{i} / c_{0} z_{0}=1 / c$ となるから， (37) 式が成立する。

$$
Y_{i}=Y-X \frac{d Y}{d X}=\frac{z_{i}}{c_{0} z_{0}}=\frac{1}{c}
$$

cはFig. 14 の S 点に関連する濃度である。

(35)，(36)式の関係を用い，(37)式より $Y$ と $d X / d Y$ を消去 すると，(38)式を得る。

$$
\begin{gathered}
-X \frac{d(c v)}{d c}+X v=\frac{1}{c} \\
\therefore \quad \frac{1}{X}=c v-c \frac{d(c v)}{d c}=(c v)^{\prime}
\end{gathered}
$$

また， $\mathrm{S}^{\prime}$ 点に特ける接線と $X$ 軸との交点は， $X-Y$ $(d X / d Y)$ であり, これは $Y_{i}(-d X / d Y)$ に等しいから，

$$
X-Y \frac{d X}{d Y}=\left(Y-X \frac{d Y}{d X}\right)\left(-\frac{d X}{d Y}\right)
$$

であり，上式の右辺第 1 項は(37)式より $1 / c$ であり， $-d X / d Y$ は(35)式より $1 / v$ であるから，

$$
X-Y \frac{d X}{d Y}=\frac{1}{c v}
$$

の関係が得られる。

(35)式と(36)式を上式に代入して，Xと $d X / d Y$ を消去す ると，(39)式を得る。

$$
\frac{1}{Y}=c-c v \frac{d c}{d(c v)}=c^{\prime}
$$

(38)式は Fig. 14 飞扔いて, 濃度 $c$ 飞相当する $\mathrm{S}$ 点に掠 ける流束曲線への接線と $c v$ 軸との交点 $(c v)^{\prime}$ の逆数の $1 /$ (cv)'がXとなり，(39)式は，Fig. 14 飞执いて，S点に 牤汀る流束曲線への接線と $c$ 軸との交点 $c^{\prime}$ の逆数の $1 / c^{\prime}$ がYとなることを示して抒り，これょり Fig. 16 のよう に清澄界面位置 $\mathrm{S}^{\prime}$ を求めることができる。

Fig. 14 の $\mathrm{S}$ 亿対応する Fig. 15, 16 上の $\mathrm{S}^{\prime \prime}$ 点の座標 は $(X=1 / c, Y=1 / c v)$ で表わされる。

Fig. 16 亿打いて，直線 $\mathrm{OS}^{\prime}$ の傾きは $U_{c}$ であり, た， $Y$ 軸の $1 / c$ とX軸の $1 / c v$ とを結ぶ直線の傾きが $U_{s}$

Vol. 11 No. 8 (1974)

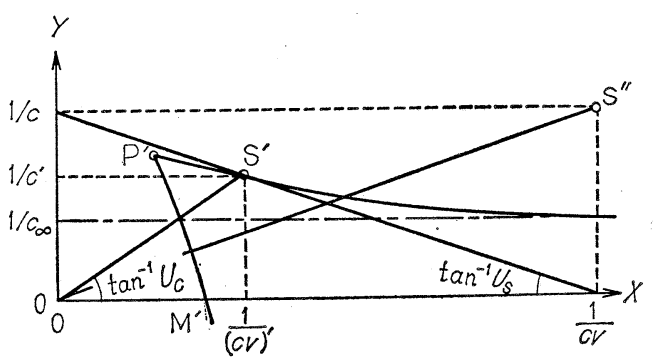

Fig. 16 Fig. 14 とX, Y面との相互関係, $c_{0} z_{0}=$ 一定

となることは，Fig. 14 とあわせて明らかである。

(35) （39)式の関係から，Fig. 14 の固体流束曲線を用い $\tau$, 上方の下降清澄界面 ( $c=0$ と $c$ の濃度不連続面) と, 濃度 $c$ の等濃度上昇層との合致点は, Fig. 16 の $\mathrm{M}^{\prime} \mathrm{P}^{\prime} \mathrm{S}^{\prime}$ 曲線のように表わされる。Fig. 14 の $\mathrm{M}, \mathrm{P}$, $\mathrm{S}$ の各点は, Fig. 16 の $\mathrm{M}^{\prime}, \mathrm{P}^{\prime}, \mathrm{S}^{\prime}$ の各点とそれぞれ相 互に関連している。この $\mathrm{M}^{\prime} \mathrm{P}^{\prime} \mathrm{S}^{\prime}$ 曲線を用いて， $c_{0} z_{0}$ が一 定の場合の回分沈降曲線を求めることができる。

\section{2 作図による方法}

(35) （39）式より，Fig. 14 を用いて $X-Y$ 曲線を作図で 求める方法を示す。

1） Fig. 17 上の固体流束曲線の最大值を $M ， M$ 上り左 側の任意の点を $\mathrm{R}$, 変曲点を $\mathrm{P}$, 変曲点より右側の任 意の点を $\mathrm{S}$ とす。各点に対応する濃度を $c_{\mathrm{R}}, c_{\mathrm{M}}, c_{\mathrm{P}}$, $c_{\mathrm{S}}$, 固体流束を $(c v)_{\mathrm{R}},(c v)_{\mathrm{M}},(c v)_{\mathrm{P}},(c v)_{\mathrm{S}}$ とする。各 点江打方流束曲線への接線と $c$ 軸との交点を $c_{\mathrm{R}}{ }^{\prime}$, $c_{\mathrm{P}}{ }^{\prime}, c_{\mathrm{s}}{ }^{\prime}$, 接線と $c v$ 軸との交点を $(c v)_{\mathrm{R}}{ }^{\prime},(c v)_{\mathrm{P}}{ }^{\prime},(c v)_{\mathrm{s}^{\prime}}$, とする。

2) Fig. 17 下の $X Y$ 面上で, $X=1 /(c v)_{\mathrm{R}}{ }^{\prime}, Y=1 / c_{\mathrm{R}}{ }^{\prime}$ が $R^{\prime}, X=1 /(c v)_{\mathrm{M}}, Y=0$ の点が $\mathrm{M}^{\prime}$ である。 $X=1 /$ $(c v)_{\mathrm{P}}{ }^{\prime}, Y=1 / c_{\mathrm{P}}{ }^{\prime}$ の点が $\mathrm{P}^{\prime}$ で尖頭点となる。他の点 も同様にして求められ，これを結べば $\mathrm{R}^{\prime} \mathrm{M}^{\prime} \mathrm{P}^{\prime} \mathrm{S}^{\prime}$ の曲 線が得られ， $\mathrm{P}^{\prime} \mathrm{S}^{\prime}$ は $1 / c_{\infty}$ に漸近する。

3） Fig. 17 上で, RはBRとORの交点であるから， Fig. 17 下に扮いて, $\tan ^{-1} \mathrm{OR}^{\prime} \mathrm{B}^{\prime}=\tan ^{-1} \mathrm{RBL}$ となる ようと引いた直線 $\mathrm{OR}^{\prime}$ と, $Y$ 軸上の $1 / C_{\mathrm{R}}$ の点 $\mathrm{K}^{\prime}$ よ り, $\tan ^{-1} \mathrm{~K}^{\prime} \mathrm{R}^{\prime} \mathrm{B}^{\prime}=\tan ^{-1} \mathrm{ROL}$ となるように引いた直線 $\mathrm{K}^{\prime} \mathrm{R}^{\prime}$ との交点として $\mathrm{R}^{\prime}$ が求められる。 $\mathrm{K}^{\prime} \mathrm{R}^{\prime}$ は $X$ 軸 と $1 /(c v)_{\mathrm{R}}$ で交わる。

4）同様にして, Fig. 17 下の $Y$ 軸上の $1 / c_{\mathrm{P}}$ の点 $\mathrm{L}^{\prime} よ$ り, $\tan ^{-1} \mathrm{~L}^{\prime} \mathrm{G}^{\prime} \mathrm{O}=\tan ^{-1} \mathrm{POL}$ と岁る直線 $\mathrm{L}^{\prime} \mathrm{G}^{\prime}$ を引き， 原点から $\tan ^{-1} \mathrm{P}^{\prime} O \mathrm{G}^{\prime}=\tan ^{-1} \mathrm{PNL}$ となるよらに引い た直線との交点を $\mathrm{P}^{\prime}$ とすれば， $\mathrm{P}^{\prime}$ は $\mathrm{P}$ と関連する点 となる。

手順(2)と手順 (3，4) は同一の結果を与えることは, 

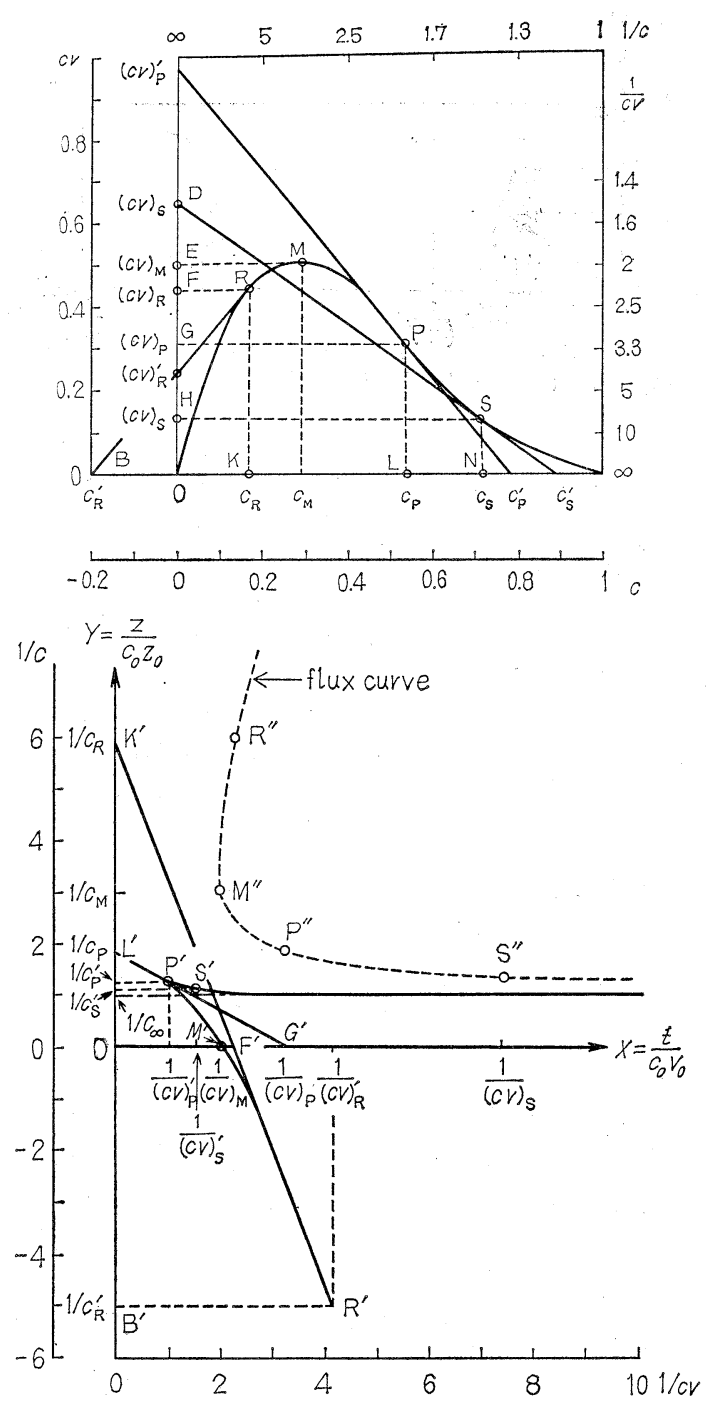

Fig. $17 X Y$ 曲線の作図法, $c_{0} z_{0}=$ 一定

明らかで岗る。参考として, Fig. 17 上の固体流束曲線

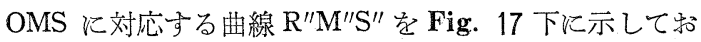
く。

Fig. 17 下で，たと党ば $\mathrm{K}^{\prime} \mathrm{F}^{\prime}$ は，初高 $z / c_{0} z_{0}=5.4$ からの濃度 $c_{\mathrm{R}}$ の層の定速沈降を示すことを用いて，回 分沈降曲線を求めることができるが，その方法は後節で 述べる。

\section{3 解析的に求める方法}

Fig. 16 の曲線を数式によって求める方法を考えてみ る。粒子群沈降速度と固体粒子濃度の間につぎのような 関係の㐫る場合には，流束曲線は(40)式で表わされる。

$$
\begin{gathered}
v=v_{g}\left(1-\frac{c}{c_{\infty}}\right)^{n} \\
c v=c v_{g}\left(1-\frac{c}{c_{\infty}}\right)^{n}
\end{gathered}
$$

$v_{g}$ は単一粒子の沈降速度である。

Fig. 14 の流束曲線に関連する $X$ の值は, (38)式と(40)式 から，(41)式のように求められる。

$$
X=\left[c v-c \frac{d(c v)}{d c}\right]^{-1}=\left[n v_{g} \frac{c^{2}}{c_{\infty}}\left(1-\frac{c}{c_{\infty}}\right)^{n-1}\right]^{-1}
$$

$X$ に対応する $Y$ の值は, (39)〜(40)式，あるいは Fig. 15 の幾何学的関係から(42)式として求められる。

$$
Y=-X \frac{d(c v)}{d c}=\frac{(n+1)\left(c / c_{\infty}\right)-1}{n c^{2} / c_{\infty}}
$$

(41) （42)式の $X$ とを求めてプロットすれば，Fig. 16 の尖頭点をもつ曲線が得られる。

Fig. 14 の最大流束点Mにたいする濃度 $c_{M}$ に扔いて は， $d(c v) / d c=0$ であるから，4g)式より，Fig. 16 では $Y=0$ であり, 対応する濃度は, $c_{M}=c_{\infty} /(n+1)$ となり, これから $\mathrm{M}$ 点に関連する $X$ を(41)式から求めると, $\mathrm{M}^{\prime}$ 点の 座標はつざのようになる。

$$
\mathrm{M}^{\prime}\left(X=\frac{(n+1)^{n+1}}{v_{g}\left(n c_{\infty}\right)^{n}}, \quad Y=0\right)
$$

また, Fig. 14 の変曲点, すなわち Fig. 16 の尖頭点 $\mathrm{P}^{\prime}$ に打いては， $d^{2}(c v) / d c^{2}=0$ より，対応する濃度 $c_{P}$ は, $c_{P}=2 /(n+1)$ であるから, (41)〜(42) 式より, Fig. 16 の $\mathrm{P}^{\prime}$ 点の座標は，つぎのように与えられる。

$$
\mathrm{P}^{\prime}\left(X=\frac{(n+1)^{n+1}}{4 n v_{g} c_{\infty}(n-1)^{n-1}}, \quad Y=\frac{\left(2 c_{\infty}-1\right)(n+1)^{2}}{4 n c_{\infty}^{2}}\right)
$$

\section{4 回分沈降曲線}

$X Y$ 面上に和ける曲線を用いて, 回分沈降曲線を作図 から求めることができる。

\subsubsection{I類沈降}

Fig. 18 上に打いて， $c_{\infty}$ から $c v$ 曲線に引いた接線と 曲線との交点 Rにたいする濃度を $c_{\mathrm{R}}$ とすると， スラリ

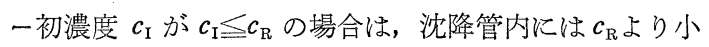
さい濃度 $c_{\mathrm{I}}$ と $c_{\infty}$ の両者の濃度しか存在しない。 いま, スラリー初濃度が $c_{\mathrm{R}}$ であるとすると, 上部清 
澄界面の沈降速度は，Fig. 18 上の $\mathrm{OR}$ R傾きで表わさ れ, これはFig. 18 下の $X Y$ 面に捻いて, $Y=1 / c_{\mathrm{R}}$ より $X Y$ 曲線の $\mathrm{P}^{\prime} \mathrm{M}^{\prime}$ 側の曲線へ引いて接線の傾きに等し く, この直線が $Y=z_{\infty} / c_{0} z_{0}=z_{\infty} / c_{\infty} z_{\infty}=1 / c_{\infty}$ の線と交わ るところまで進んで沈降を終了し，それ以降は高さ $z_{\infty} /$ $c_{0} z_{0}$ で一定である。これは I類沈降である。

5.4 .2 II 類沈降

スラリ一初濃度が Fig. 19 上の $c_{\mathrm{R}}$ と, 流束曲線の変 曲点 $\mathrm{P}$ に対応する濃度 $c_{\mathrm{P}}$ との間にある場合には, $X Y$ 面上飞怙ける沈降曲線は, 定速沈降, 圧密沈降, 沈降終 了の3区間にわかれ，ABとAC間が不連続に移行する 類沈降となる。

Fig. 11 はII類沈降曲線で, A 層は清澄層で $c=0$, $\mathrm{B}$ 層はスラリ一初濃度 $c_{\mathrm{II}}\left(c_{\mathrm{R}}<c_{\mathrm{II}}<c_{\mathrm{P}}\right), \mathrm{C}$ 層の濃度は $c_{I 1} \sim c_{\infty}, \mathrm{D}$ 層の濃度は $c_{\infty}$ である。

管底から上昇する等濃度層のらち， Fig. 19 上に招い て， $c_{\text {II }}$ から流束曲線へ引いた接線の接点に対応する濃 度層がもっとも早く上昇し, $c_{11}$ との間に濃度不連続界面 が形成され，气の上昇速度は接線の傾きで表わされる。

沈降曲線は， $Y$ 軸の $1 / c_{11}$ の点から下方曲線 $\mathrm{P}^{\prime} \mathrm{M}^{\prime}$ 一引 いた接線が， $\mathrm{P}^{\prime} \mathrm{T}^{\prime}$ 曲線と交わる点まで定速沈降となり, 以後, $\mathrm{P}^{\prime} \mathrm{T}^{\prime}$ 曲線に沿って $1 / c_{\infty}$ の線と交わる点まで圧密 沈降, それ以後は $1 / c_{\infty}$ の一定となり，Fig. 19 下のよ らになる。

スラリー初濃度が $c_{\mathrm{P}}$ の場合には， $Y$ 軸の $1 / c_{\mathrm{P}}$ と $\mathrm{P}^{\prime}$ を
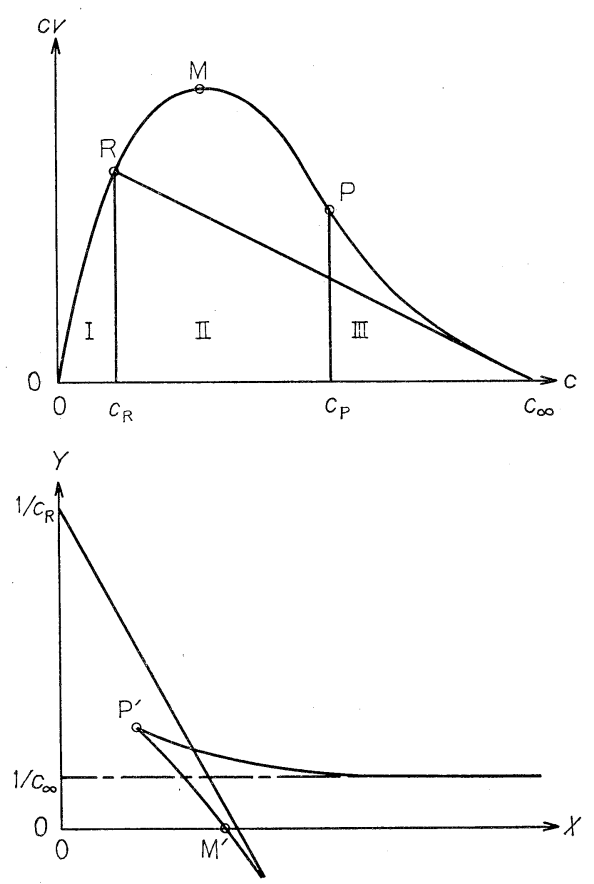

Fig. 18 I 類沈降, $c_{0} z_{0}=$ 一定
結ぶ直線が定速沈降区間となり，以後は $\mathrm{P}^{\prime} \mathrm{T}^{\prime}$ に沿って $1 / c_{\infty}$ にいたる沈降曲線となる。

\section{4 .3 且類沈降}

スラリ一初濃度が $c_{\mathrm{III}}$ で, $c_{\mathrm{P}}<c_{\mathrm{III}}<c_{\infty}$ の場合には, もっとも早い等濃度上年層の濃度は $c_{I I I}$ であり, I, II 類にみられるよらな上年界面は存在せず，且類沈降とな る。

沈降曲線としては, $Y$ 軸の $1 / c_{I I I}$ より曲線 $\mathrm{P}^{\prime} \mathrm{T}^{\prime}$ に接 線を引き, 接点まで定速沈降, 接点以降は $\mathrm{P}^{\prime} \mathrm{T}^{\prime}$ に沿っ た圧密沈降となる (Fig. 19)。

以上述べた $X Y$ 面上飞括ける沈降曲線を, $z-t$ 面に 特ける沈降曲線として表わすためには， $X$ 軸と $Y$ 軸の值 とそれぞれ $c_{0} z_{0}$ の值をか子てやればよい。

\section{6. 遠心沈降}

遠心力場飞掠けるスラリーの沈降では, 遠心力が回転 中心からの距離により異なることを考慮しなければなら ない。

Fig. 20 の上らに, 遠心力沈降容器の回転軸中心から の距離が $r_{1}$ と $r_{2}$ との間に岗る $\Delta r$ の区間をとり，沈降 推進力としての遠心力が，回転軸に直角方向に作用して いるとする。回転角速度を $\omega$, 濃度 $c$ のスラリ一の重力 場に括沙る沈降速度を $v$, 重力加速度を $g$, 粒子が微小 で層流域で沈降すると考光ると, 回転中心から

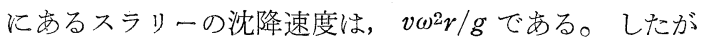
って, 沈降方向金直な断面の単位面積を単位時間に通
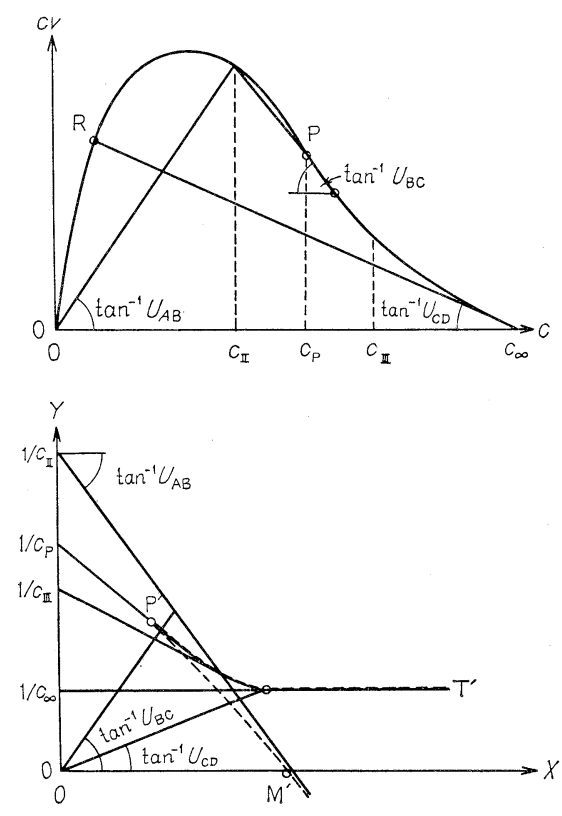

Fig. 19 II , II 類沈降曲線, $c_{0} z_{0}=$ 一定

Vol. 11 No. 8 (1974) 


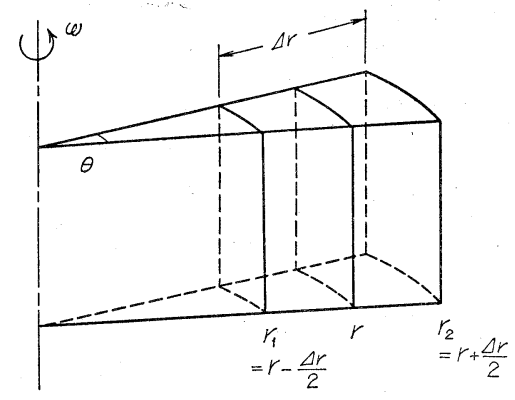

Fig. 20 回分遠心沈降

過する固体量, すなわら固体粒子沈降流束はつぎのよう に表わされる。

$$
c v \omega^{2} r / g=s \omega^{2} r c
$$

$$
\text { ただし } s=s(c)=v(c) / g
$$

Fig. 20 に和いて, $r-\Delta r / 2$ の面にたいする $\Delta t$ 時間 の固体粒子流入量は，次式で表わされる。

$$
\left[s \omega^{2}\left(r-\frac{\Delta r}{2}\right) c \Delta t\right]\left(r-\frac{\Delta r}{2}\right)\left(\frac{\theta}{2 \pi}\right)
$$

また, $r+\Delta r / 2$ 面分らの固体粒子流出量は次式で表わ される。

$$
[s+\Delta s] \omega^{2}\left(r+\frac{\Delta r}{2}\right)^{2}\left(\frac{\theta}{2 \pi}\right)(c+\Delta c) d t
$$

さらに, $\Delta r$ 間の固体粒子の蓄積量は, $r(\theta / 2 \pi) \Delta r \Delta c$ で 㐫るから，つぎの物質収支が成立する。

$$
\begin{aligned}
& s \omega^{2}\left(r-\frac{\Delta r}{2}\right)^{2} c-(s+\Delta s) \omega^{2}\left(r+\frac{\Delta r}{2}\right)^{2}(c+\Delta c) \\
& =r \Delta r \Delta c
\end{aligned}
$$

これを整理すると, 次式が得られる。

$$
\frac{\partial c}{\partial t}+\frac{1}{r} \frac{\partial}{\partial r}\left[\omega^{2} r^{2} s(c) c\right]=0
$$

$s_{0}=s(0) と し$

$$
\frac{s}{s_{0}}=\frac{v}{v_{g}} \equiv \phi(c), \quad \tau \equiv \omega^{2} s_{0} t, \quad \rho \equiv \frac{r}{r_{1}}
$$

とおくと，(44)式は(45)式となる。

$$
\begin{array}{r}
\frac{\partial c}{\partial \tau}+\frac{1}{\rho} \frac{\partial}{\partial \rho}\left[\rho^{2} \phi c\right]=0 \\
\therefore \quad \frac{\partial c}{\partial \tau}+\rho(\phi c)^{\prime} \frac{\partial c}{\partial \rho}+2 \phi c=0
\end{array}
$$

$c(\rho, \tau)$ と考光て全微分をとると，(46)式が得られる。

$$
d c=\frac{\partial c}{\partial \rho} d \rho+\frac{\partial c}{\partial \tau} d \tau
$$

$$
\therefore \quad \frac{\partial c}{\partial \tau}+\frac{d \rho}{d \tau} \frac{\partial c}{\partial \rho}-\frac{d c}{d \tau}=0
$$

(45)式と(46)式を比較すると，つぎの関係の牧ることが知 られる。

$$
\frac{d \rho}{d \tau}=\rho(\phi c)^{\prime}
$$

$$
\frac{d c}{d \tau}=-2 \phi c
$$

$\rho=\xi$ におけるスラリ一初濃度が $c_{0}(\xi)$ であるとして, (48)式を積分すると，(49)式が得られる。

$$
2 \tau=-\int_{c_{0}}^{c} \frac{d c}{\phi c}
$$

また，(47)式を(48)式で割って得られる式を，(49)式と同一 の初期条件で積分すると，(50)式が得られる。

$$
\begin{array}{rlrl}
-2 & \int_{\xi}^{\rho} \frac{d \rho}{\rho} & =\int_{c_{0}}^{c} \frac{(\phi c)^{\prime}}{\psi c} d c \\
\therefore \quad\left(\frac{\rho}{\xi}\right)^{2} & =\frac{c_{0} \psi_{0}\left(c_{0}\right)}{c \phi(c)}
\end{array}
$$

沈降セルの長さを $r_{1}$ から $r_{2}$ の範团に限定しているの で, $r_{2}$ の面に最大濃度 $c_{\infty}$ のスラジが堆積する。濃度不 連続界面の生成速度は, (47)式より

$$
\frac{d \rho}{d \tau}=\rho \frac{\phi\left(c_{1}\right) c_{1}-\phi\left(c_{2}\right) c_{2}}{c_{1}-c_{2}}
$$

であるから，スラジ界面の上昇速度は，上式で $c_{2}=c_{\infty}$ と して(51)式のようになる。 


$$
\left(\frac{d \rho}{d \tau}\right)_{1, \infty}=-\rho \frac{\psi\left(c_{1}\right) c_{1}}{c_{\infty}-c_{1}}
$$

また, 清澄界面の沈降速度は, $c_{1}=0$ として, (52)式と なる。

$$
\left(\frac{d \rho}{d \tau}\right)_{0.2}=\rho \psi\left(c_{2}\right)
$$

スラリーの初期状態として, 容器中に少量の固体粒子 が均一に分散して括り, 粒子群沈降速度 $v$ と, 単一粒子 沈降速度 $v_{g}$ の間に, (11)式と同㥞に(53)式が成立すると仮 定する。

$$
\phi(c)=\frac{v}{v_{g}}=1-\frac{c}{c_{\infty}}
$$

(53)式を用いれば，(49)式を積分することができる。

$$
\begin{gathered}
-2 \tau=\int_{c_{0}}^{c} \frac{d c}{c\left(1-\frac{c}{c_{\infty}}\right)} \\
\therefore-2 \tau=\ln \left(\frac{c}{c_{0}}\right)\left(\frac{c_{\infty}-c_{0}}{c_{\infty}-c}\right)
\end{gathered}
$$

これより, $c$ はつぎのように求められる。

$$
c=\frac{c_{0} e^{-2^{\tau}}}{1-\frac{c_{0}}{c_{\infty}}\left(1-e^{-2^{\tau}}\right)}
$$

(54)式を(50)式に代入すると， $\rho$ は(55)式のように求められ る。

$$
\rho=\xi e^{\tau}\left[1-\frac{c_{0}}{c_{\infty}}\left(1-e^{-2^{\tau}}\right)\right]
$$

清澄界面の位置 $\rho_{t}$ は, (52)式で $c_{2}=c$ とし, (18)式の $d \tau$ $=d c /-2 \phi c$ を代入し, $\rho=1$ で $c=c_{0}$ として積分し， (54) 式の $c$ を代入すれば,つぎのように求められる。

$$
\rho_{t}=e^{\tau}\left[1-\frac{c_{0}}{c_{\infty}}\left(1-e^{-2 \tau}\right)\right]^{1 / 2}
$$

また，底部のスラジ沈積高さ $\boldsymbol{r}_{b}$,すなわち $\boldsymbol{r}_{b} / \boldsymbol{r}_{1} \equiv \rho_{b}$ に ついては, (51)式で $c_{1}=c$ とすれば

Vol. 11 No. 8 (1974)

$$
\frac{d \rho}{d \tau}=-\rho \frac{\left(1-\frac{c}{c_{\infty}}\right) c}{c_{\infty}-c}=-\rho \frac{c}{c_{\infty}}
$$

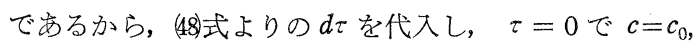
$\rho=r_{2} / r_{1} \equiv R$ として積分すると, 次式が得られる。

$$
\begin{aligned}
& \int_{R}^{\rho_{b}} \frac{d \rho}{\rho}=-\frac{1}{c_{\infty}} \int_{0}^{\tau} c d \tau=\frac{1}{c_{\infty}} \int_{c_{0}}^{c} \frac{d c}{2 \psi}=\frac{1}{2 c_{\infty}} \int_{c_{0}}^{c} \frac{d c}{1-\frac{c}{c_{\infty}}} \\
& \therefore \quad \frac{\rho_{h}}{R}=\left[\frac{c^{\infty}-c}{c_{\infty}-c_{0}}\right]^{-1 / 2}
\end{aligned}
$$

したがって，これに(54式の $c$ を代入し，つぎのように $\rho_{b}$ を求めることができる。

$$
\rho_{b}=R\left[1-\frac{c_{0}}{c_{\infty}}\left(1-e^{-2 \tau}\right)\right]^{1 / 2}
$$

清澄界面とスラジ沈積面が一致し， $\rho_{t}=\rho_{b}$ になったと きに，沈降は終了する。このときの時間 $\tau_{1}$ は(56) $=577$ 式 より,つぎのようになる。

$$
\tau_{1}=\ln R
$$

さきに， $\tau \equiv \omega^{2} s_{0} t$ と定義したので， $\tau_{1}=\ln R$ のときの 沈降終了時間 $t_{1}$ は, 次式となることが知られる。

$$
t_{1}=\frac{\ln R}{\omega^{2} s_{0}}
$$

(53)式が仮定されるようなスラリーの回分遠心沈降過程 を Fig. 21 亿示す。

\section{7. 流動層における等濃度層の移動}

粒子群全体が速度 $u$ で上昇している場合の等濃度層の 移動速度は，(2)式と(6)式より，u<0として，つぎのよ うになる。

$$
\left(\frac{d z}{d t}\right)_{c}=-\frac{d(c v)}{d c}-u
$$

流動層飞执いては, $u$ は流動化速度 (空塔) で, 静止 流体中の粒子群沈降速度 $v$ に等しいから, (58)式は(59)式と なる。

$$
\left(\frac{d z}{d t}\right)_{c}=-\frac{d(c v)}{d c}+v
$$


ここで, 固体容積分率 $c$ の粒子群の静止流体中の沈降 速度 $は$, 単一粒子沈降速度を $v_{g}$ とて,

$$
v=v_{g}(1-c)^{n}
$$

の関係があれば4)，cvは次式で表わされる。

$$
c v=c v_{g}(1-c)^{n}
$$

(59)式に(60)式を入れれば, 等濃度層の上梨速度をつぎの ように求めることができる8)。

$$
\left(\frac{d z}{d t}\right)_{c}=n c v_{g}(1-c)^{n-1}
$$

流動;開始時, あるいは, 濃度 $c$ で流体空塔速度 $u=v$ で均一に流動している層の空塔速度を变え, 濃度を少し 変化させ, 再び安定させるような場合に, 等濃度層の上 升が認められる99。

\section{8. 沈降管断面積の変化}

これまでは，沈降方向に直角な管断面積は一定である としてきたが, 回分沈降に执いて, 沈降管断面積が沈降 方向に小さくなっている場合について考光てみる。

Fig. 22 のように， $z$ 軸を沈降の逆方向に正にとり， $z$ と $z+\Delta z$ 亿执汀る沈降管断面積を，それぞれ $A$ 拉よび $A+\Delta A, A=A(z), \Delta A>0$ とする。

回分沈降衹いて, 長さ $\Delta z$ 間を $\Delta t$ 時間涌過する固 体粒子流量の収支はつぎのようになり，627式が成立す る。

$(c v)(A+\Delta A) \Delta t-[c v-\Delta(c v)] A \Delta t=A \Delta c \Delta z$

$$
\frac{\partial c}{\partial t}=c v \frac{\partial A}{A \partial z}+\frac{\partial(c v)}{\partial z}
$$

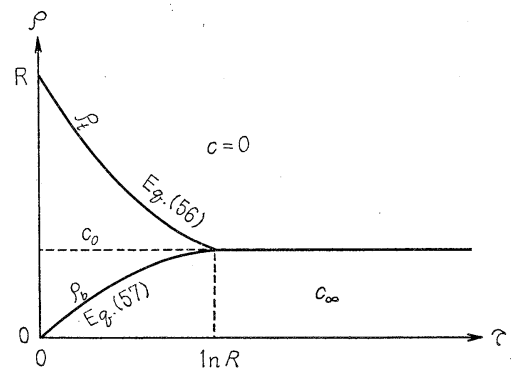

Fig. 21 回分遠心沈降曲線。(53)式を仮定した場合
$A(z)$ であるから，管断面積が一定であれば，62式の 右辺第 1 項は 0 となり，(4)式に等しくなることが知られ る。

沈降管断面積が沈降方向に増加している場合には，上 述したような物質収支に，傾斜壁の影響を付加して考兄 る必要があると思われる。

\section{9. スラリー輸送過程の濃度変化}

Fig. 23 のように，スラリーがD E間は水平， E F 間 は垂直，F G 間は再び水平に，定常状態で流孔ている場 合について考㝋てみる。

系への流入量を $Q\left[\mathrm{~m}^{3} / \mathrm{sec}\right]$, 粒子群沈降速度を $v[\mathrm{~m} /$ $\mathrm{sec}$, スラリ一濃度を $c\left[\mathrm{~m}^{3}-\mathrm{solid} / \mathrm{m}^{3}\right.$-slurry $と し$, 水平流入部と流出部を $f$, 垂直沈降部を 2 の添字をつけ て表わすと，Fig. 23 の点線部の物質收支より，次式が 成立する。

$$
c_{f} Q=c_{2} v_{r 2} A
$$

ただし， $v_{r 2}=v_{2}+u$

\section{$Q=u A （ \mathrm{~A}$ は B C間の流れに直角方向の断面} 積)

したがって,上の 2 式より次式が得られる。

$$
c_{f} u=c_{2} v_{2}+c_{2} u
$$

$v_{2}$ と $c_{2}$ は未知であるが，このスラリーの固体流束曲 線が既知であれば，作図的に求めることができる2,10)。

Fig. 24 飞招いて, 緃軸上の点 $\mathrm{M}\left(\mathrm{OM}=c_{f} u\right)$ を, 横 軸上の点 $\mathrm{L}\left(\mathrm{OL}=c_{f}\right)$ を結ぶ直線を引き, 流束曲線との 交点を $\mathrm{Y}$ すると， $\mathrm{Y}$ 点に相当する濃度 $\mathrm{ON}=c_{2}, \quad \mathrm{Y}$ 点 飞相当する流束 $\mathrm{OP}=c_{2} v_{2}$ となり，(63)式と $c v(c)$ を満足 する $c_{2}$ と $v_{2}$ を求めることができる。

垂直下降流中のスラリ一濃度 $c_{2}$ は給液濃度 $c_{f}$ より常

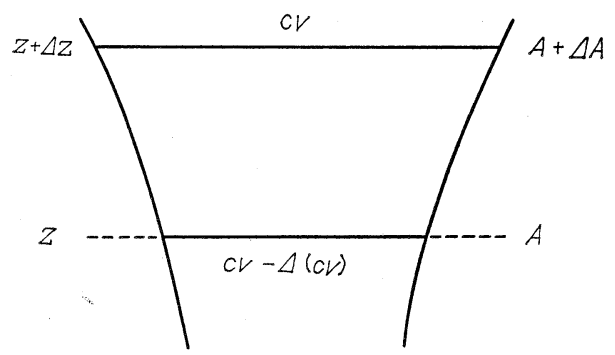

Fig. 22 沈降断面積の変化 


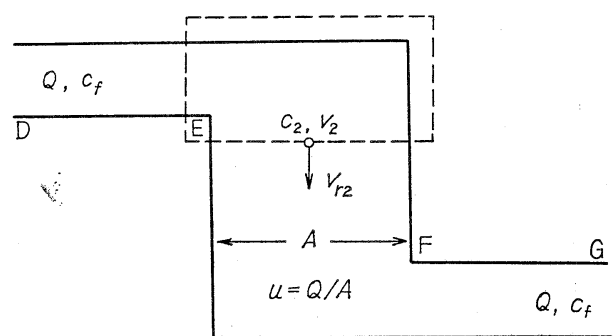

Fig. 23 下向流を含む沈降性スラリ一輸送の定常状態

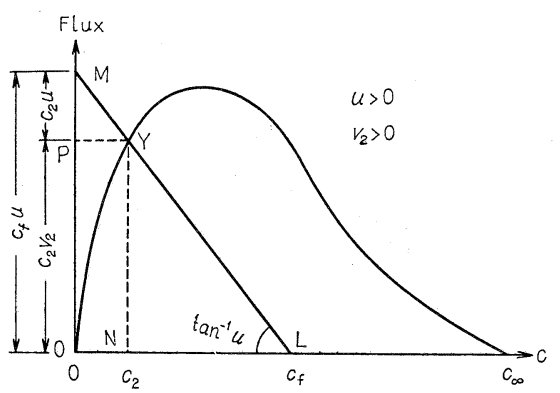

Fig. 24 沈降性スラリーの下降流に和ける濃度の困解法 に小さい。それは，63)式を書き直すと，

$$
\frac{c_{2}}{c_{f}}=\frac{1}{1+\left(v_{2} / u\right)}
$$

となり， $u \rightarrow \infty て ゙ ~ c_{2} \rightarrow c_{f}$, また $u \rightarrow 0$ で $c_{2} \rightarrow 0$ となるこ とからも知られる。

スラリーがFig. 23 のから入ってF E 間を上昇し， 再び水平路 $\mathrm{E} \mathrm{D}$ を通る場合も同様で，この場合には，u $<0$, 器壁にたいするけん濁固体粒子の相対沈降速度 $v_{r 1}<0$ として，(63)式が成立する。

F E 間の求める濃度を $c_{1}$ とすると， Fig. 25 に拈い て，(63)式の直線と流束曲線との交点 $\mathrm{Y} よ り ， v_{1}$ と $c_{1}$ が 得られる。極限值として, $u \rightarrow \infty$ で $c_{1} \rightarrow c_{f}, u \rightarrow 0$ で $c_{1} \rightarrow c_{\infty}$ である。

以上から，スラリーが流路中を Fig. 26 のうに一方 向に流れている場合, Fig. 26 上の $\mathrm{E}, \mathrm{F}, \mathrm{G}, \mathrm{H}$ の各 箇所の濃度は不連続に変化して，Fig. 26 下のようにな り， $\mathrm{EF}$ 間で $c_{2}, \mathrm{GH}$ 間で $c_{1}$ で， $c_{f}$ にはなっていない

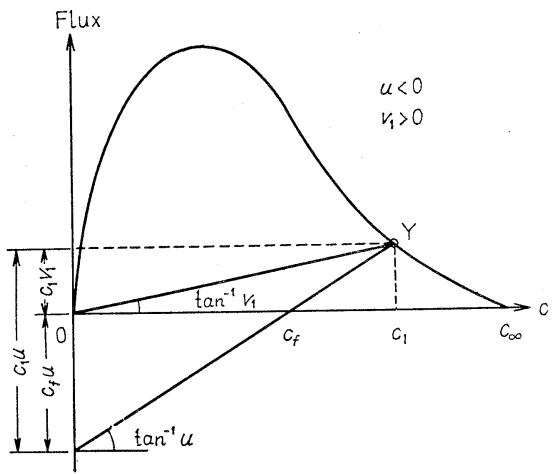

Fig. 25 沈降性スラリーの上昇流における濃度の図解法

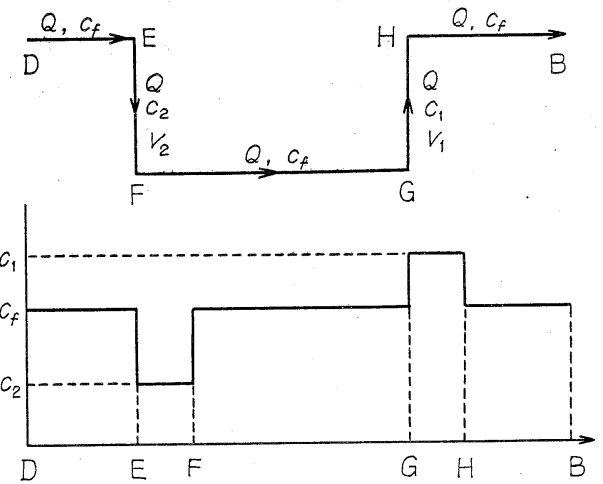

Fig. 26 沈降性スラリ一流の輸送方向変化による濃度変化

ことが知られるであろう。

また, 粒子が終末速度に達する所要時間はきわめて短 かいので, 濃度は急激に変化する。

\section{結言}

スラリーの沈降に和ける濃度不連続界面と, 等濃度層 の伝播について，固体流束曲線を用いて解析できること を中心にして述べた。これはさらに, 沈降濃縮槽や, 沈 降性スラリーのろ過などの問題の解析にも利用されるこ とが期待される。

討論や作図法などは小幡英二助手, 文献輪読には大学 院学生杉谷照雄と佐藤輝昭, 図表浄書には大学院学生坂 下幸司等の諸氏の協力を得た。ここに感謝の意を表す る。

$$
\begin{aligned}
c & : \text { 容積分率濃度 } \\
V & : \text { 容積 } \\
A & : \text { 容器断面積 } \\
z & : \text { 高さ } \\
t & : \text { 時間 }
\end{aligned}
$$

Vol. 11 No. 8 (1974)
記 号

$$
\begin{aligned}
Q & : \text { 容積流量 } \\
v g & : \text { 重力場静水中の単一粒子沈降速度 } \\
v & : \text { 重力場静水中の粒子群沈降速度 } \\
c v & : \text { 固体粒子容積流束 } \\
u & : \text { スラリー流速 }
\end{aligned}
$$




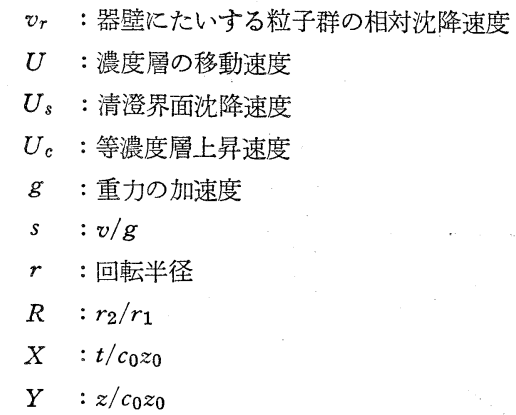

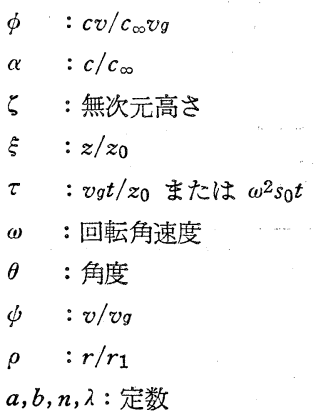

引用 文 献

1) Kynch, G.J. : Trans. Faraday Soc., 48, 166 (1952)

E. 2) Straumann, R. : Chem. Ing. Tech., 40, 383 (1968).

3) Jernqvist, A. S. H. : Sv. Papperstidning, 68, 506 ? (1965)

4) Richardson, J. F., and Zaki, W. N. : Trans. Inst. Chem. Engrs., 32, 35 (1954)

5) Shannon, P. T., Stroupe, E., and Tory, E. M. : IEC. Fund., 2, 203 (1963)

6) Aris, R., and Amundson, N. R. : "Mathematical Methods in Chemical Engineering", Vol. 2., p.234,
Prentice-Hall, Inc., 1973.

7) Hassett, N J. : Ind. Chemist., 34, 489-494 (1958)

8) Wallis, G. B. : Symp. Interaction Fluid Particles, Inst. Chem. Engrs. (London), p.9-16 (1962)

9) Willus, G. A. : “An Experimental Investigation of Particle Motion in a Liquid Fluidized Bed”, p. 74, ARL 72-0018 (1972)

10）吉岡直哉, 堀田 豊, 由中 晋 : 化学工学, $21,66-74$ (1957)

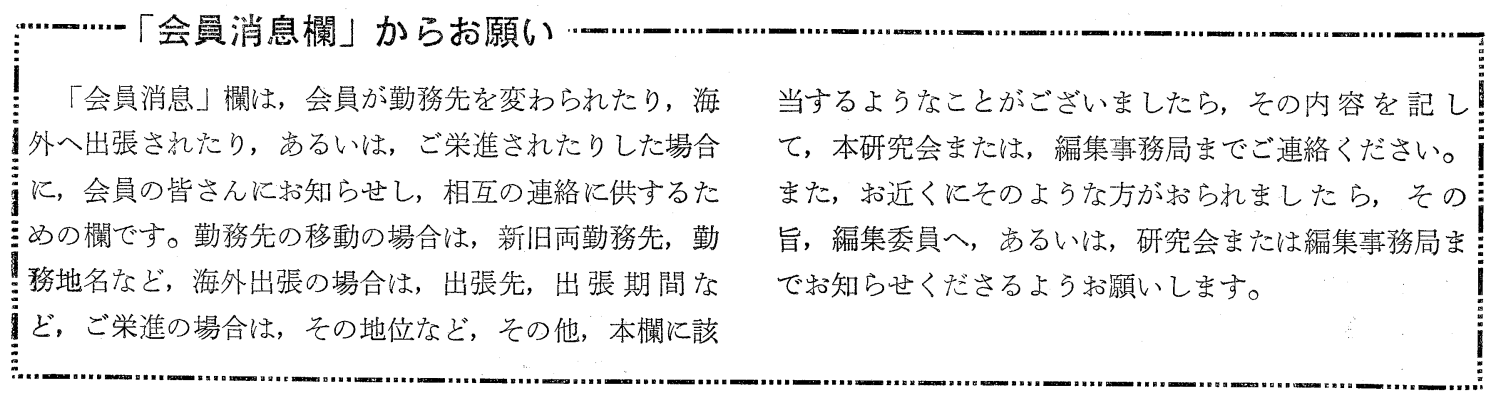

